\title{
The Budget Deficit Financing Impact on the Real Exchange Rate in Egypt (1975-2020)
}

\author{
Mohamed A. Eldepcy ${ }^{1}$ \\ ${ }^{1}$ Department of Economic, Faculty of Economics and Political Science, Cairo University, Giza, Egypt \\ Correspondence: Mohamed A. Eldepcy, Department of Economic, Faculty of Economics and Political Science, \\ Cairo University, Giza, Egypt. Tel: 201-001-652-940.
}

Received: January 20, 2022

Accepted: February 11, 2022

Online Published: February 20, 2022

doi:10.5539/ijef.v14n3p84

URL: https://doi.org/10.5539/ijef.v14n3p84

\begin{abstract}
The Purpose of this paper is to examines empirically The causal impact of budget deficit financing methods on real exchange rate in Egypt during the period from 1975 to 2020.The main question of the paper whether there is a causal relationship between the large fluctuations in the real exchange rate and budget deficit/GDP proportion, governed by specific predictable factors, in particular the method of financing the budget deficit.

Using structure vector autoregressive (SVAR) framework with variable lag structure, our empirical results provide evidence of the contribution of the money supply ratio to the GDP in the fluctuations of the real exchange rate in the short and medium terms, while the contribution of non-bank financing expressed in the real interest rate contributed to a lesser degree in these fluctuations, which gives an indication of the expansion in the use of local bank financing to finance the budget deficit during the study period. Moreover, the results showed that the government's dependence on local sources in financing the budget deficit was large, especially the local bank financing. It was also found that the non-banking domestic sources of funding have less influence on the fluctuations of the real exchange rate and therefore the value of the Egyptian pound relative to the US dollar. furthermore, also found out that the periods in which the real exchange rate index decreased and the value of the pound improved, are the periods in which the reliance on non-banking domestic financing was greater than on domestic banking financing, namely the periods from 1993-1997, and from 2005-2010.
\end{abstract}

This paper aims to contribute to filling the gap in the applied literature that examined the relationship between the budget deficit and external imbalance by focusing on the role of the means of financing the budget deficit.

Keywords: real exchange rate, banking financing, non-banking financing, external financing, Budget deficit, SVAR

\section{Introduction}

\subsection{The Problem Identification}

Chronic fiscal deficit considered the most important challenge facing developed and developing countries alike. Financing this fiscal deficit often cause macroeconomic internal and external imbalances and creates high fluctuations in interest rate and exchange rate.

Most countries, both developed and developing alike, have been searching since the beginning of the eighties of the last century for appropriate policies to modify this deficit and avoid its negative effects, this issue is more clear and urgent in developing countries after budget deficit has become one of its main financial features and a major indicator of economic performance, so Reducing the budget deficit to GDP ratio is a basic requirement to achieve fiscal sustainability while avoiding the negative social impacts of policies addressing this issue.

The emergence of large budget deficit considers one of the main features of the internal economic imbalances in the Egyptian economy since 1975. One is concerning the constraints that the financing of increased fiscal deficits poses for real exchange rate volatility. The relationship between the budget deficit and the real exchange rate in Egypt was implicitly examined when studying the relationship between the external and internal imbalances and in the context of studying the applicability of the Twin deficit hypothesis (budget deficit and trade balance deficit) and the extent of the validity of the Ricardian equivalent hypothesis, as well as in the context of studying the impact of the budget deficit and its financing on Inflation, and within the framework of estimating the equilibrium real exchange rate in Egypt. 
Given the importance and necessity to investigate the large fluctuations in the real exchange rate because of its important impact on the competitiveness of Egyptian exports, especially in light of the contradiction between the movements of this important variable with the movement of the budget deficit/GDP ratio. This was done using an exactly identified SVAR approach. The results of the two models used in the paper confirm that the factors that significantly contributes in RERI fluctuations in the long term are the ratio of the budget deficit to the GDP and the rate of growth of the GDP. Therefore, reducing the proportion of the budget deficit to the GDP is one of the important policies to achieve stability in the real exchange rate and the value of the Egyptian pound relative to the dollar.

\subsection{Theoretical Views}

Conventional wisdom - as well as mainstream macroeconomic models used by policymakers — suggests that the high budget deficit and the method of financing it affect many macroeconomic variables. When the government finances this deficit through domestic borrowing, it pushes the real interest rates to rise on domestic financial assets, thus the rate of return on them increases compared to the return on foreign financial assets, which leads to an increase in foreign capital inflows, increasing supply of foreign currency, and improve the value of the local currency in relative to the foreign currency in local exchange market (seater, 1993).

The equivalent hypothesis attributed to the classical economist Ricardo also shows that the method of financing the budget deficit through domestic borrowing does not affect the value of the local currency in relation to the foreign currency because the increase in government borrowing is the result of a lack of government saving, which will be compensated by an increase in private saving that does not affect the total saving and therefore the real interest rate will not be affected, foreign capital flows will not be affected, and the value of the local currency will not be affected, and the reason for the increase in private saving at the present time is Individuals and the private sector re-planning their consumer spending in the long term in light of the increase in the budget deficit at the present time, and thus their expectation that the government will raise taxes in the future to finance its debt service (Barro, 1988). On the other hand, A fundamental principle of economy macroeconomics That in order to have a sustainable and stable macroeconomic equilibrium it is necessary for monetary and fiscal policies to be consistent with the chosen nominal exchange rate regime (Edwards, 1987).

\subsection{Empirical Literature}

Edwards (1989) analyze real exchange rate (RER) behavior in twelve developing countries for the period 1960-1985 using theoretical and empirical model. The theoretical model suggests that (RER) movements have responded to both real and nominal disturbances in short run but only responds to real disturbances in long run. The main conclusion of the empirical model is that the macroeconomic disequilibria affect the (RER) in the short run, while (RER) responds to changes in fundamental in the long run. This paper uses the budget deficit / high power money ratio and the domestic credit / real income ratio as indicators to macroeconomic disequilibria.

Macmillin and Koray (1990) has examined the effects of the market value of privately held U.S. and Canadian government debt on the real Canadian dollar/U. S, dollar exchange rate using a small vector autoregressive model that includes in addition to debt and the exchange rate--output price level, nominal money, interest rate, and government purchases variables for both the United States and Canada. Variance decompositions based on this model indicate significant effects of debt on the exchange rate while impulse response functions indicate that debt shocks lead to a short-lived depreciation of the U.S. dollar rather than to an appreciation as conventional theory would suggest.

Darrat and Sulimanb (1991) examines empirically the causal impact of monetary and fiscal policy on exchange rates and interest rates in Canada using a six-by-six vector autoregressive (VAR) model with variable lag structure. The results suggest that changes in the base money and budget deficits have no direct causal effects on exchange rates, a finding consistent with the monetary explanation that exchange rates follow a random walk. Also consistent with the Ricardian equivalence hypothesis, the results reveal no direct effect of budget deficits on interest rates, casting doubts on the crowding-out phenomenon for Canada. In contrast, changes in the base money unidirectional cause changes in interest rates, implying some support for using interest rates as a key intermediate policy target for the Canadian monetary authorities.

Apergis (1998) examine empirically the relationship between budget deficits and exchange rates within a multi-country sample over the period 1980-1995 using the quarterly time series data on nominal budget deficits, exchange rates defined as nominal effective exchange rates, real GDP at 1990 prices, prices measured by the consumer price index, and money supply measured as M1, for eight OECD countries, Germany, the UK, Switzerland, Belgium, The Netherlands, Italy, France, and Canada. Empirical analysis employed the co integration as well as the causality approach and it demonstrated that in the long run only the UK, Switzerland, 
France, and Canada characterized by a relationship between budget deficits and exchange rates. In addition, long-run causality was detected, indicating that budget deficits tend to cause exchange rates. In the short run, in countries where an anti-inflationary policy was not followed in a strict manner, i.e. Italy Belgium, and France, higher budget deficits seem to suggest the presence of a depreciating exchange rate. For the remaining countries, higher budget deficits suggest that the domestic currency appreciates.

Stoker (1999) examined the economic effects of the deficit spending on the exchange rate in the short and long terms using the two-country cash in advance model. He found that increases in deficit spending result in a short-term appreciation of the currency. In the long term however, it leads to a temporary or permanent depreciation of the currency depending on the method used to finance the deficit. If it is financed by taxation, the depreciation of the currency is temporary but if it is financed by money growth, the decline in the value of the currency is permanent.

Khan, Akhtar, and Rana (2002) examined the relationship between exchange rate and budgetary deficit in Pakistan for the period 1982-1998 under the managed floating exchange system. The Multiple regression model ordinary least squares method used for analysis. The result shows that budget deficit has both direct and indirect effects on the real exchange rate; the exchange rate Changes depend on whether the fiscal deficit is reduced by increasing taxes or by lowering government expenditures with the devaluation being lower if the cut in government expenditure falls on traded rather than non-traded goods. The paper also concluded that budget deficits had a negative effect on the real exchange rate, and that the overall budget deficit had no relation with the nominal exchange rate, but the real exchange rate, and that the overall budget deficit had no relation with the nominal exchange rate, but the budget deficit financed by banking system led to higher nominal interest

$\mathrm{Su}$ and $\mathrm{Su}$ (2003) re-examined the relationship between budget deficits and exchange rates by Applying Hakkio's (1996) model to seven Asian countries and eight Euro-currency countries over the years from 1951 to 2001. Applying the Time-Series Cross-Section Regression with the Seemingly Unrelated Regression approach to data from 15 countries, the results indicate that because of the indirect effect of the expected inflation rate, the risk premium, and the expected return rate, currency values inversely related to budget deficits. However, the empirical results also present evidence supporting the Ricardian Equivalence Proposition that there is no direct effect of budget deficits on exchange rates.

Srivyal and Venkata (2004) studied the interaction of budget deficit of India with other macroeconomic variables such as Nominal effective exchange rate, GDP, Consumer Price Index and money supply (M3) giving special emphasis on the budget deficit-exchange rate relationship using Co integration approach and Variance Error Correction Models (VECM) for the period 1970-2002. The results reveal that the variables under study are co integrated and there is a bi-directional causality between budget deficit and nominal effective exchange rates.

Kim and Roubini (2008) examined the effect of government deficits on the current account and the real exchange rate in the US for the post Bretton Wood period of flexible exchange rate covering 1973:1-2004:1 using a VAR. The variables include government deficits expressed as a percentage of the GDP, the current account deficits expressed as a percentage of GDP, the real percentage of the GDP, the current account deficits expressed as a percentage of GDP, the real interest rate and the real exchange rate. They also include the $\log$ of real gross domestic product to control for the cyclical component of the fiscal deficits. Contrary to Keynesian theory, their results suggest that an expansionary budget deficit shock improves the current account and depreciates the real exchange rate.

Monacell and Perotti (2010) employ Vector Auto Regression (VAR) techniques to estimate the effects of fiscal policy and, in particular, government spending on the CPI real exchange rate and the trade balance in the US and three other OECD countries, sample runs from 1980:1 to 2006:4. The empirical analysis delivers two key results. First, a rise in government spending tends to induce a real exchange rate depreciation and a trade balance deficit, although, especially in the US, the latter effect tends to be small. Second, in all countries private consumption rises in response to a government spending shock and, therefore, co-moves positively with the real exchange depreciate.

Enders et al. (2011) provides new evidence on the dynamic effects of government spending and technology shocks on the real exchange rate and the terms of trade, using vector auto regressions on U.S. time series relative to an aggregate of industrialized countries, over the period (1975-2005), Depending on nine key macroeconomic variables: gross domestic product, terms of trade, government spending, inflation, investment, budget balance, interest rate, net exports, and real exchange rate. The results show that both the real exchange rate and the terms of trade-whose responses are left unrestricted-depreciate in response to expansionary government spending shocks and appreciate in response to positive technology shocks. 
Wuyah and Amwe (2015) adopted Vector Auto-regression method in analyzing the impact of fiscal deficits on macroeconomic variables in Nigeria for the period of 1970 to 2013. The empirical results show that fiscal deficits have positive impact on inflation, and negative impact on money supply and exchange rate. Therefore concluded that fiscal deficits have significant impact in Nigeria.

Dissanayake (2016) examines the relationship between budget deficit and selected macroeconomic variables including the exchange rate in Sri Lanka. Using annual time series data for the post-liberalization period, 1980-2014. The ARDL bounds test used to determine whether there is a relationship between budget deficit and the selected variables Granger Causality test carried out to determine the nature of causality between the selected variables and budget deficit. The results revealed that there is a long-run relationship between budget deficit and the exchange rate in Sri Lanka.

Nwaeze (2017) examined the relationship between fiscal deficits, modes of financing it and macroeconomic stability in Nigeria from 1970 to 2016. The study used inflation rate and exchange rate as proxies for macroeconomic stability whereas overall fiscal deficits, fiscal deficit financed by domestic borrowing, fiscal deficit financed by external borrowing, interest rate, money supply, foreign direct investment, and external reserve balance were used as the endogenous variables. The study employed co-integration and VAR estimation methods to analyze the data. The results of the variance decomposition reveal that interest rate, overall fiscal deficits and the size of fiscal deficits financed by domestic borrowing are the main shocks causing the variation in inflation, while overall fiscal deficits, the size of fiscal deficits financed by external borrowing and the size of fiscal deficits financed by domestic borrowing are the main shocks causing the variation in exchange rate in Nigeria. The study concluded that fiscal deficits have significant negative impact on macroeconomic stability (represented by inflation and exchange rates) in Nigeria.

Adebayo and George (2019) investigate the relationship between government financing of deficit through the bond market and its effects on the exchange rate in Nigeria over the period 1986-2016. The study makes use of secondary annual time series data to examine the relationship between bond financing and the exchange rate. In this regard, empirical models formulated to explain the relationship between bond financing and the exchange rate, and the formulated models estimated using the ARDL bounds test and the Johansen co integration approaches. The result shows that bond financing has a weak positive relationship with the exchange in Nigeria. With regard to the components of bond financing, bond financing through the banking system depreciates the exchange rate while financing by the non-bank public leads to exchange rate appreciation. It was recommended that increasing effort made by the government to further develop the bond market and encourage greater non-banking public participation in the market.

Saxena and Singh (2020) investigate the dynamic relation between exchange rate and government deficit in India during a period from April 2001 to March 2017. The results of VAR Granger causality found unidirectional causality that moves from exchange rate to government deficit. ARDL co-integration test results exhibit no long run relation between the variables. The results of Impulse Response Function indicate that government deficit responses positively to the one SD shock in exchange rate; exchange rate, in the similar fashion responses positively to the one SD shock in government deficit. The variance decomposition results indicated that a shock to the exchange rate causes 2.069 percent fluctuation in the government deficit in short run, and up to 9.04 percent in long run, while a shock to government deficit does not cause any fluctuation in the exchange rate in short run and in long run, a shock to government deficit causes 3.65 percent fluctuation in the exchange rate that is very less.

Ayinde and Bankole (2021) investigates fiscal dominance and exchange rate stability in Nigeria. The period of investigation spanned 1981q1-2018q4, and the Structural Vector Auto regression (SVAR) technique employed to test the fiscal dominance hypothesis and further examine the shock transmission effects of fiscal deficit components such as budget deficit and public debt on exchange rate movement in Nigeria. As a robustness, Autoregressive Distributed Lag (ARDL) technique employed to analyze the shock transmission effects of these components on the movement of exchange rate in Nigeria. More so, granger causality test conducted to trace the direction of causality among the fiscal deficit components and the exchange rates. The results show that budget deficit and changes in exchange rates in Nigeria have bi-causal relationship, while public debt could not granger cause exchange rate movement in the country. The SVAR estimates suggests that exchange rate movement in Nigeria reacted only to the shock effects of financial openness and the ARDL results indicate that both public debt and budget deficit have destabilizing effects on exchange rates in Nigeria.

The relationship between the budget deficit and the real exchange rate in Egypt was implicitly examined when studying the relationship between the external and internal imbalances, and in the context of studying the 
applicability of the Twin deficit hypothesis (budget deficit and trade balance deficit), and the extent of the validity of the Ricardian equivalent hypothesis, as well as in the context of studying the impact of the budget deficit and its financing on Inflation, and within the framework of estimating the equilibrium real exchange rate in Egypt.

Marinheiro (2007) estimated the impact of the budget deficit on the current balance deficit in Egypt and examined the applicability of both the Ricardian equivalent hypothesis and the twin deficit hypothesis in Egypt with the aim of advising the policy maker on the appropriate method to reduce the budget deficit. The results of this applied study using annual data for the period from 1974-1989 showed the rejection of the Ricardian equivalent hypothesis in Egypt during the mentioned period, where an increase in the budget deficit by one pound led to an increase in total consumption by 0.43 pounds, meaning that the increase in the budget deficit led to an increase in consumption and did not accompanied by an increase in private saving, and thus the need for external financing appears for the budget deficit, which leads to the emergence of twin deficit.

Nazier and Essam (2012) in the context of studying the impact of fiscal policy on the current account and the real exchange rate during an annual time series for the period from 1992 to 2010 using a structural autoregressive model, and it was found from the theoretical examination of the data on the primary deficit in the general budget, the current account deficit and the real exchange rate, the twin deficit hypothesis does not apply, as the increase in the primary deficit in the public budget was accompanied by an improvement in the current balance during the period from 1999 to 2002 and the period from 2004 to 2006, and the improvement in the primary budget deficit (its decrease) was accompanied by a deterioration (increase) in the current account deficit during the period 1992 to 1994 and during 2007. On the other hand, the second half of the nineties and the period from 2008 to 2010 witnessed a deterioration in both variables (an increase in the budget deficit and the current balance deficit), and the correlation was weak between the primary budget deficit and the current account deficit $(0.42)$, as well as the weak correlation between the primary budget deficit and the real exchange rate of the Egyptian pound is (0.27), which gives an indication that both the primary budget deficit and the real exchange rate do not move in the same direction during the mentioned period. Therefore, the study suggested the so-called double deviation instead of the twin deficit the study concluded that there is practical evidence that the budget deficit shocks lead to an improvement in the current account and lead to a decrease in the real exchange rate (improving the value of the pound relative to the dollar).

Noureldin (2017), estimated the real exchange rate in Egypt and its deviation from its equilibrium level using quarterly data during the period from the third quarter of 2001 until the third quarter of 2017. The applied results showed that the Egyptian pound overvalued by $24 \%$ at the end of the third quarter of 2016. The flotation policy that was followed on November 3, 2016 led to the Egyptian pound losing 32\% of its actual value, which means that the real value of the pound decreased by $14.7 \%$ in the fourth quarter of 2016, meaning that after the pound was overvalued, it became undervalued after the floating, and the decline in the real value of the pound increased to $22.3 \%$ in the first quarter of 2017 , before the decline reached $18.5 \%$ in the third quarter.

Abdelghani (2020) examined the effect of money supply (M2), trade openness (the ratio of total exports and imports to GDP) and foreign exchange reserves as independent variables on the real exchange rate as a dependent variable during the period of implementing economic reform (1990-2018). Co-integration using the distributed lag model (ADRL), in which the long-run relationship is estimated and the error-correcting model (ECM), which estimates the relationship in the short run. The results of the co-integration analysis showed that there is a long-term relationship between the study variables at a level of morale of $1 \%$. It was also shown that both money supply and foreign exchange reserves have a significant positive impact on the real exchange rate in the long term, as when foreign exchange reserves increase by $1 \%$ the real exchange rate rises by $0.1 \%$. The study explained that the increase in foreign exchange reserves with the Central Bank leads to a decrease in the supply of foreign currency in the exchange market, and thus its value increases and the value of the pound decreases. When the money supply increases by $1 \%$, the real exchange rate rises by 1.12 , which means a depreciation of the pound.

\section{Method}

\subsection{Nominal and Real Exchange Rate Movements in Egypt (1975 to 2020)}

\subsubsection{Nominal Exchange Rate}

The Figure 1, reflects the movements of the nominal exchange rate index NERI during the period from 1975 to 2020 (base year 2010). It shows the existence of a general upward trend, albeit with a slight increase until 1990, which is the stage before the economic reform, which characterized by liberalization and unification of the exchange rate. The rise in the NERI of the US dollar relative to the pound continued during the two phases of 
economic reform (1990-2003), However, the exchange value of the dollar relative to the pound tended to decline, but at a small rate during the period (2005-2010), and this period is the only period that witnessed an improvement in the nominal value of the pound relative to the dollar, which followed the stage of the managed flotation in 2003.

During the period from 2010-2016, the exchange value of the dollar to the pound rebounded to an upward trend, but at a small rate. This period witnessed the instability of the foreign exchange market and the re-emergence of the black market for foreign exchange, which led to the intervention of the Central Bank by adopting several policies to reduce imbalances in the foreign exchange market as a result of the low revenue the state's foreign exchange and the low level of economic activity due to the political and social transformations that resulted from the events of the January 2011 and June 2013 revolutions. This intervention led to the deterioration of the foreign exchange reserve balance with the Central Bank in 2016. We also note from the aforementioned chart that a sharp rise in the exchange rate of the dollar to the pound occurred from the end of 2016 to the end 2018, by approximately $87 \%$, until the nominal exchange rate index stabilized at the beginning of 2019 and then headed to decline by a small percentage.

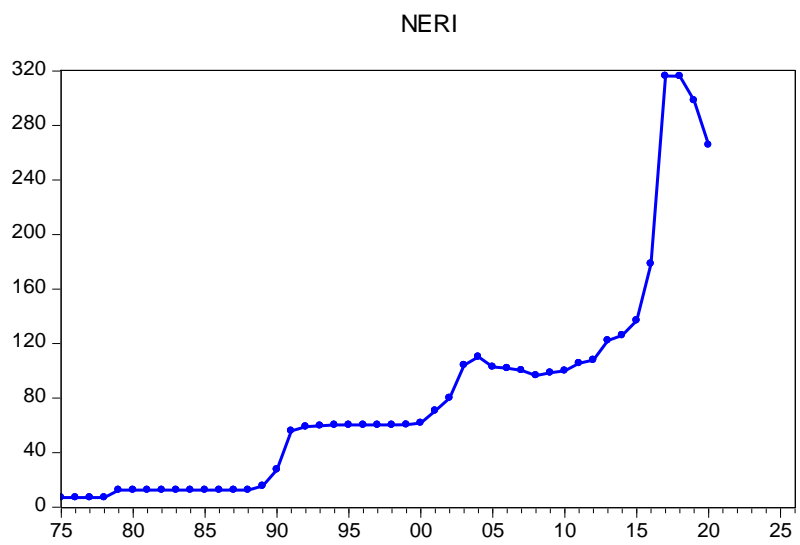

Figure 1. Movements of the NERI of the dollar against the pound

\subsubsection{Real Exchange Rate}

Although exchange rate volatility affects the domestic price of foreign goods, adjustments that merely offset existing inflation differentials do not alter competitive position. Therefore, economist construct for analytical purposes real exchange rate (RER) index, which remove changes in relative price levels from NER movements. Changes in the real exchange rate influence foreign trade flaws, balance of payments, the structure and level of production, allocation of resources, etc. while the (RER) is an endogenous variable that responds to both exogenous as well as policy-induced shocks.

As for the real exchange rate index (Note 1), calculated on the basis of taking into account the change in price levels in the United States and Egypt, (base year 2010), it appears from Figure 2, that there were noticeable fluctuations in it that tend to rise (the depreciation of the pound relative to the dollar) in general during the period from 1975-2019. Although these fluctuations were few during the period from 1975-1980, they began to increase sharply to the upside during the period from 1980-2019, which means that there were large fluctuations in the real value of the dollar in relative to the pound, and these fluctuations were oscillating between rise and fall. The aforementioned chart also showed that the periods of decline in which the value of the pound improved relative to the dollar were (1980-1990), (1995-2000) and (2005-2010). We note that the improvement in the first period was due to the intervention of the Central Bank to stabilize the exchange rate and stabilize the price level.

As for the period from 1995 to 2000 and the period from 2005 to 2010, it was due to the adoption of reform policies of the foreign exchange market accompanied by significant inflows of foreign exchange, whether in the form of loans from state institutions or grants as a result of Egypt's political position in the first and second Gulf wars, and because of the improvement in the ability of Egyptian exports to increase receipts from Foreign exchange and the correlation of corrective economic policies with reducing the volume of aggregate demand which consequently reducing the volume and value of imports and improving the value of foreign exchange receipts. 


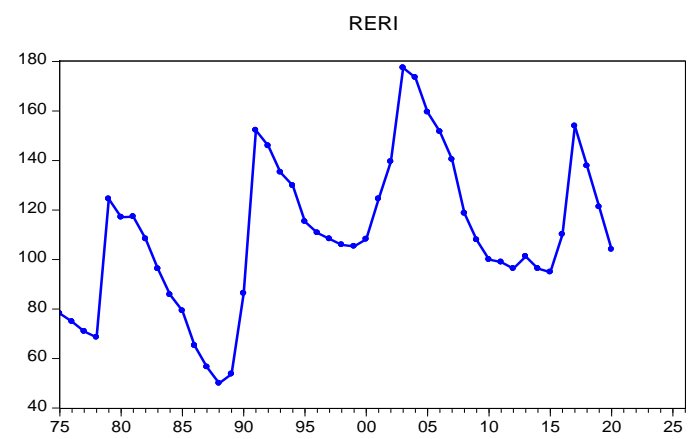

Figure 2. Movements of the RERI of the dollar against the pound

\subsection{Budget Deficit and Its Sources of Financing}

The overall deficit in the public budget means the difference between the total public expenditures and the total public revenues plus to the net acquisition of capital assets. It represents the net annual borrowing (net change of public debit) or net annual financing needs, and it differs from the total annual borrowing or total financing needs in that the latter includes the amount repaid from old loans with new loans.

The overall deficit financing sources are divided into domestic financing and external financing. Domestic financing sources are classified into domestic bank financing and domestic non-bank financing, Domestic non-bank financing means that the government obtains the financing from the National Investment Bank from the proceeds of selling investment certificates (government bonds) and borrowing from individuals' savings indirect through mailboxes authority and from the surplus of the Social Insurance Authority. It also includes sales of bonds and treasury bills to the public, and supplier facilities. As for the net domestic banking finance (Note 2) or monetary financing, it includes borrowing from the central bank and commercial banks, in the form of purchasing treasury bills and bonds, as well as in the form of bank credit, from which government deposits with the banking system are subtracted (the difference between government withdrawals and its deposits with banking system. As for external financing, it takes the form of external borrowing from financial institutions and international banks, or withdrawal from the foreign exchange reserve with the Central Bank, and it calculated by net flows, which is the difference between external debt service payments and annual receipts from external borrowing (Taha, 2011).

\subsubsection{Budget Deficit Movement}

The Figure 3, show the movements of the budget deficit ratio to GDP, during the period from 1975 to 2020 .It is clear that this percentage was high during the period from 1975 to 1990, where It reached an average of $23.5 \%$. During the period from 1991 to 2010 , this percentage was on average $4.8 \%$ due to the application of economic reform policies, most of which focused on reducing public spending more than increasing public revenues, which was linked to policies restricting aggregate demand, this led to reducing this percentage to less than $1 \%$. of the GDP in 1996, but this percentage quickly returned to increase after that until it reached $8.1 \%$ in 2009 as a result of the start of the four national projects (Toshka, Northwest Suez, North Sinai development, and East Tafria port) during the period from 1997 to 2010 . This percentage continued to increase during the period from 2011 to the end of 2016 due to the effects that faced the Egyptian economy as a result of the January 2011 and June 2013 revolutions, and ranged between $10 \%$ and $13 \%$ until it tended to decline from the beginning of the fiscal year 2017/2018 to 6.3\% in the estimates of the budget for the year Financial 2020/2021.

$\mathrm{BD}$

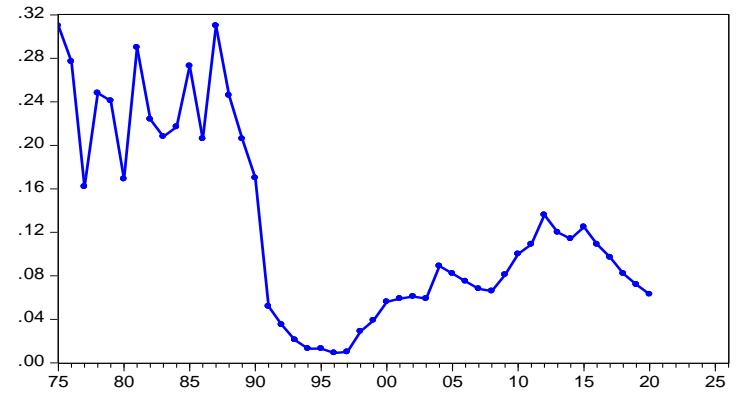

Figure 3. The movements of the budget deficit ratio to GDP 


\subsubsection{Domestic and External Financing (Note 3)}

As for the sources of financing the total deficit shown in Figure 4, it classified into domestic financing and external financing. The average ratio of domestic financing to the overall deficit during the period from 1975 to 1990 was $70 \%$ and external financing 30\%, while during the period from 1991 to 2019, the domestic financing percentage increased until it exceeded 100\% in the years from 1994 to 2005 and reached $167 \%$ in some years during this period, and the average ratio during the period as a whole was $108 \%$, and on the other hand, the percentage of external financing was very small and was negative in the period from 1994 to 2005 that is, the general budget pays loan installments and interest abroad that exceed what it receives from loans from abroad, and the percentage of external financing on average during the period as a whole was $0.015 \%$.

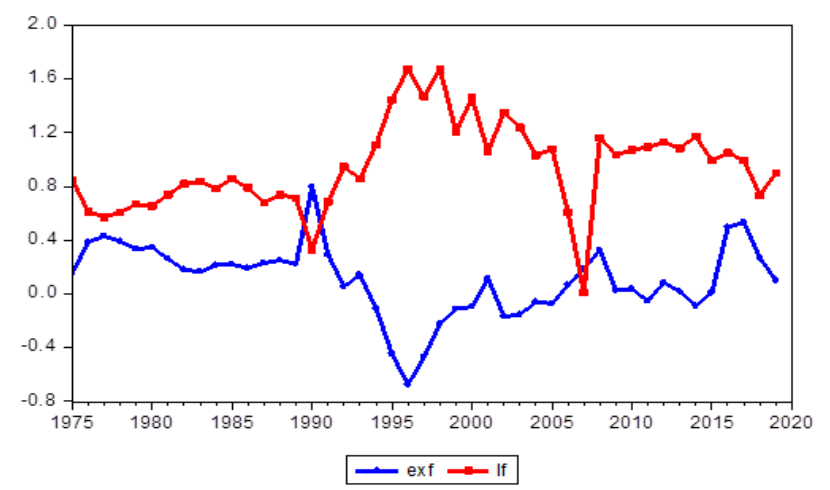

Figure 4. Domestic financing and external financing ratio to overall deficit

\subsubsection{Bank and Non-Bank Financing}

The domestic financing divided, in turn, into bank financing and non-bank financing. The non-bank domestic financing is mainly individual savings, represented in the resources of the National Investment Bank from the proceeds in the Postal Savings Fund and from the proceeds of the sale of investment certificates and balances of the Social Insurance Authority, the local non-bank financing also includes the resources that are available from non-bank sources such as the proceeds from the sale of treasury bills and bonds to the public and the facilities of suppliers. As for bank financing, it includes borrowing from the central bank and commercial banks in exchange for treasury bills and bonds, as well as in the form of bank credit, from which government deposits with the banking system subtracted. It is clear from figure 5, that the percentage of bank financing to the overall deficit ranged between $20 \%$ and $93 \%$ in the period from 1975 to 1990, and it was on average $48 \%$ of overall deficit, while non-bank financing ratio during the mentioned period ranged between $25 \%$ and $70 \%$, and it was in the average is $47 \%$ of overall deficit.

In general, there was stability in the relationship between the two ratios, and this was consistent with the application of the fixed exchange rate system, which limits the ability of the Central Bank to finance the deficit, and also limits its ability to generate revenues from the inflation tax, so the average inflation rate during this period was $12.3 \%$, although the average budget deficit ratio to GDP during this period was $23.5 \%$, which is considered a large ratio.

During the period from 1990 to 2019, the ratio of bank financing for the overall deficit ranged between $-56 \%$ in 1991 to $211 \%$ in 2019 and it averaged $66 \%$ during this period. The negative sign of this ratio means that the government deposits with the banking system were greater than its withdrawals, and therefore The government has reserves that can later be used to finance the deficit, and the contribution of the budget deficit to inflation in the periods when this ratio is negative means the contribution of the budget deficit to reducing inflation (meaning that the ratio of the increase in the banking system's liabilities to the money supply was less than GDP growth rate) from 1991 to 1994 and during 2006 and 2007. At the beginning of the 2006/2007 fiscal year, the government liquidated its debts to the National Investment Bank by transferring the bank's obligations to the Insurance and Social Security Fund to become obligations of the government directly to the fund. As for the rest of the fund's balance, it was deposited in the government's accounts with the banking system, which explains the reason for this the huge deposits in the mentioned fiscal year, whose use in financing the budget deficit in the following fiscal year, led to reducing the percentage of the total deficit of the GDP to its lowest level during the study period (CBE, 2006/2007). 


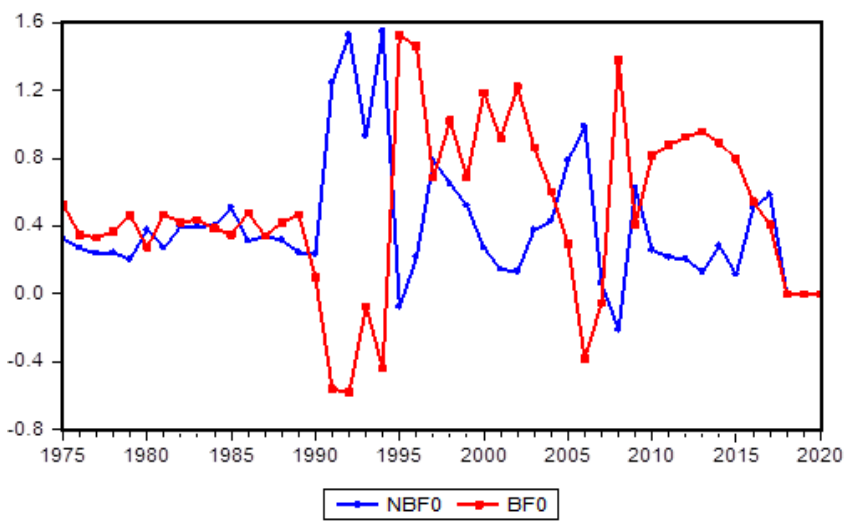

Figure 5. Ratio of bank and non-bank financing for the overall deficit

As for the percentage of non-bank financing for the deficit, it moves in the exact opposite of the percentage of bank financing, as shown in Figure 5, and it is limited by the government's ability to mobilize the required financing from individual's savings, especially through this sector's purchases of government bonds, which is considered one of the best Funding sources if they are employed in financing government investment spending necessary to achieve the desired development rates.

Based on the previous literature, the budget deficit may lead to a decrease in the real exchange rate (the improvement in the value of the pound relative to the dollar) in the short term and an increase in the real exchange rate (the deterioration of the value of the Egyptian pound relative to the dollar) in the long term if reliance is on non-bank domestic financing. On the other hand, it may lead to an increase in the real exchange rate (the deterioration of the value of the Egyptian pound relative to the dollar) in the short and long terms if relying mainly on local bank financing.

\subsection{Problem Statement}

Referring to the data of the real exchange rate index, we note that this index increased from 78.2 in 1975 to 83.3 in 1990, which means that the value of the Egyptian pound fell relative to the dollar by approximately $8.1 \%$. The main feature of the exchange rate system in this period was the absence of a single price law. During the period from 1991 to 2003, the real exchange rate index rose from 152.1 to 177.4 , meaning That the value of the Egyptian pound fell relative to the US dollar by approximately $25.3 \%$, this period was characterized by the adoption of an exchange rate system based on pegging the pound to the dollar within the framework of implementing an economic reform program. During the period from January 2003 to November 2016, the real exchange rate index decreased from 177.4 to 110 , which means that the value of the pound rose relative to the dollar by approximately $67.4 \%$. This period characterized at the beginning of it by central bank announcement of the Egyptian pound's flotation, and announcement at the end of it, adoption of several measures to correct foreign exchange policies.

As for the beginning of the implementation of the economic reform program at the end of 2016 and the beginning of 2017, the real exchange rate index rose from 110 to 153 , which mean that the value of the pound depreciated relative to the dollar by nearly $43 \%$. During 2018, the real exchange rate index decreased from 153 to 137 , which mean that value of the pound relative to dollar is appreciated by $16 \%$.

Given the impact of fiscal policies, in particular the budget deficit policy, on the real exchange rate, we note from the data on the budget deficit /GDP ratio during the mentioned periods that this ratio was also unstable and volatile, as it decreased from $31 \%$ in 1975 to $17 \%$ in 1990, This was accompanied by a decrease in the value of the pound relative to the dollar. During the period from 1991 to 2002, the budget deficit /GDP ratio increased from $5.2 \%$ to $6.1 \%$, which mean that the increase in the budget deficit accompanied with decreasing in the value of the pound relative to the dollar.

During the period from January 2002 to November 2016, the budget deficit /GDP ratio increased from $6.1 \%$ to 10.9 , meaning that the increase in the budget deficit accompanied by an improvement in the value of the pound relative to the dollar. With the beginning of the implementation of the economic reform program at the end of 2016 and the beginning of 2017, the budget deficit rate of GDP decreased from $10.9 \%$ to $6.3 \%$ in 2020 , meaning that the decrease in the budget deficit accompanied by an increase in the value of the pound relative to the dollar.

Given the importance and necessity to investigate these large fluctuations in the real exchange rate because of its 
important impact on the competitiveness of Egyptian exports, especially in light of the contradiction between the movements of this important variable with the movement of the budget deficit/GDP ratio. Therefore, the main question of the paper is whether there is a causal relationship between the large fluctuations in the real exchange rate and budget deficit/GDP ratio, governed by specific predictable factors, in particular the method of financing the budget deficit.

Table 1. Relationship between budget deficit and real exchange rate (1975-2020)

\begin{tabular}{cccc}
\hline period & Budget deficit/GDP ratio $(\mathrm{bd})$ & Real exchange rate index (RERI) & E.g. pound value /US dollar \\
\hline $1975-1990$ & $31 \%---17 \% \downarrow$ & $78 \%---152 \%$ & $-74 \%$ \\
$1990-2002$ & $17 \%---6.1 \% \downarrow$ & $152 \%---177.4 \%$ & $-25.4 \%$ \\
$2002-2016$ & $6.1 \%----10.9 \%$ & $177.4 \%--110 \% \downarrow$ & $67 \%$ \\
$2016-2020$ & $10.9 \%---6.3 \% \downarrow$ & $110 \%---137.7 \%$ & $-27.7 \%$ \\
\hline
\end{tabular}

Source: Calculated by the author.

\subsection{Data and Methodology}

As it is clear from Table 1, that the increase in the budget deficit was accompanied by real exchange rate appreciation and depreciation in the Egyptian pound value relative to the US dollar during the study period which is consistent with macroeconomic analysis mainstream and previous theoretical literature. In order to examine the nature of this relationship and Whether the expression of the budget deficit in terms of its financing components can provide an explanation of this inverse relationship, or provide advice to the decision maker to determine the financing method that reduces the fluctuations on the real exchange rate. Therefore, the methodology used in this paper depends on the employ of a structural autoregressive analytical framework (SVAR) comparing the results of two models. The first model consists of five variables: the GDP growth rate, ratio of budget deficit to GDP, real interest rate on the Egyptian pound as approxy of domestic non-bank financing, broad money supply as a percentage of GDP as approxy of domestic banking financing, real exchange rate index. we will replace the ratio of budget deficit to GDP in the second model by dividing its components into three variables: domestic non-banking financing, domestic bank financing and external financing without real interest rate and board money supply. Several recent empirical studies used VAR models to analyze the relationship between budget deficit and exchange rate. These models allow for dynamic interactions among variables and employ minimal identifying restrictions, which do not depend on a specific theoretical model.

\section{Results}

\subsection{The First Model Results}

The first model includes five variables, (gdp) which are the GDP growth rate as a kay macroeconomic variable that reflects the level of annual economic performance of the Egyptian economy during the study period, it also reflects the business cycle effects on the budget deficit and the real exchange rate, the second variable is (ddbd) the ratio of budget deficit to GDP, which reflects real side effects of the budget deficit. The second difference was used because the variable is un stationary in the level and first difference, (rir) is the real interest rate, (m2) is the ratio of board many supply to GDP, finally (lreri) is the log real exchange rate index calculated on the basis of taking into account the change in price levels in the United States and Egypt during the period from 1975 to 2020, (base year 2010), the logarithm was used because the variable is un stationary in the level and first difference, the rest of the variables are stationary in the level. The estimated model based on annual data for the period from the fiscal year $1975 / 76$ to $2019 / 20$. The data obtained from international financial statistics and time series data for the Central Bank of Egypt.

Structural autoregressive models SVAR used to capture the dynamic impact of fiscal policy (budget deficit shocks) on the current account and the exchange rate. The results of these models help us to describe the dynamic interdependence between the variables used in the model by expressing each variable in terms of its previous values and the preceding values of other variables, in addition to the error term that does not suffer from serial correlation.

An important issue in SVAR identification is that the announcement of the budget deficit policy and the expected net financing needs precede the actual implementation of this policy and therefore affect some other variables during the implementation period through expectations. On the other hand, the level of economic activity and the business cycle simultaneously affect many economic variables, so that variables included in the model were ordered on this basis (Mountford \& Uhlig, 2009), SVAR models are therefore explicit about contemporaneous relationships between variables in order to ensure identification (Corsetti \& Muller, 2009a). Our first VAR model 
includes three lags for each endogenous variable as the lag order selection criteria: HQ, AIC indicate. Once the SVAR is estimated, impulse response functions (IRF) generated based on its reduced form.

Blanchard and Quah (1989) proposed an identification method based on the restrictions on the long-run properties of the IRFs. This identification requires choosing 10 [n (n-1)/2] elements of the long-run moving average coefficient matrix, after normalizing the shocks and assuming that the structural disturbances are mutually uncorrelated. Normalizing the variances of the SVAR shocks to unity means that the impulse response of model variables generated by setting $\varepsilon$ to unity is the effect of a structural shock on the model variables of the size of one standard deviation (Reside, 2004). The zero restrictions correspond to a lower triangular matrix, which is similar to that used by Ahmed et al. (1993) and Rogers (1999). This lower triangular matrix implies that the first variable reacts to its own lags and the first shock, the second variable to its own lags and the first two shocks and so on. The method of identification imposes no restrictions on the short-run movements of the variables.
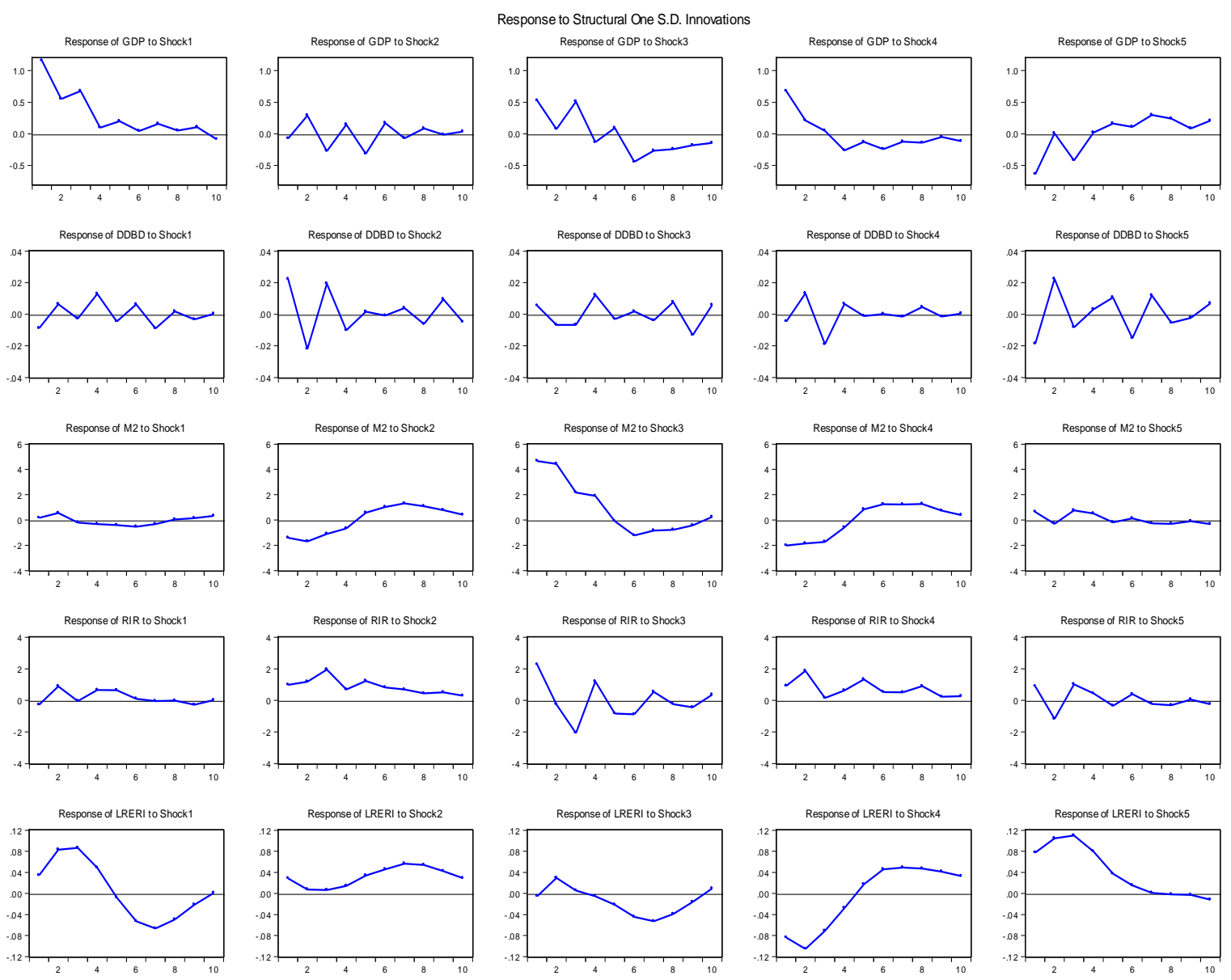

Figure 6. Impulse Responses of the first model

Note. Shocks 1, 2, 3, 4, and 5 correspond to a 1 standard deviation (s.d.) shock in gdp, ddbd, rir, m2, and lreri, respectively.

\subsubsection{Impulse Response Functions}

An impulse response function (IRF) usually used with vector auto regression (VAR) to keep track on the time path of shocks experienced by different variables in the model. Our focus will be on the fifth row of Figure 6, from which it is clear that the effect of the first shock (GDP growth rate) on the real exchange rate led to an appreciation in the real exchange rate in the first and second years of the shock, then stabilized at this level until it started to decline from the fourth year until the eighth year, then returned to the height again until the end of the impact of the shock in the tenth year. It is also clear from the second shock (increasing the budget deficit ratio to GDP by one standard deviation) depreciation in the real exchange rate in the short term and an appreciation in the long term. Which may indicate that the real factors associated with the ratio of the budget deficit to the GDP, such as the increase in government spending, the decrease in government revenues, or the decrease in the gross domestic product played an influential role in the depreciation in the real exchange rate in 
the short term and its appreciation in the long term. As evidenced by the third shock (the real interest rate) the real exchange rate appreciation in the short term and its depreciation in the long term until it returns to its original level 10 years after the shock. As for the fourth shock (the ratio of money supply to GDP), the real exchange rate depreciation in the short term and its appreciation significantly in the long term.

\subsubsection{Forecast Error Variance Decomposition}

Forecast error variance decomposition (FEVD) is a part of structural analysis, which "decomposes" the variance of the forecast error into the contributions from specific exogenous shocks over time horizon, it also demonstrates how important a shock is in explaining the variations of the model variables and Shows how that importance changes over time.

Table 2. Forecast error variance decomposition for RERI

\begin{tabular}{cccccc}
\hline shocks & gdp & bd & rir & $\mathrm{m} 2$ & reri \\
\hline 1year & 7.8 & 5.4 & 0.18 & 46.6 & 39.8 \\
5years & 21.7 & $2 . .7$ & 1.7 & 29.5 & 44.5 \\
10 years & 23.4 & 10.8 & 6.7 & 28.2 & 30.8 \\
\hline
\end{tabular}

As shown from Table 2, the effect of the four shocks on the error variance of the real exchange rate increased from $60 \%$ in the first year to $69.2 \%$ in the long term. The most influential variables in the short term were the money supply ratio to GDP, which decreased from $46.6 \%$ in the first year to $28.2 \%$ in the long term, which is consistent with the fact that the impact of monetary variables on the real exchange rate is neutral and decreases in the long term, followed by the GDP growth rate, whose effect increased from $7.8 \%$ in the first year to $23.4 \%$ in the long term. It is also clear that the effect of the real interest rate increased from $0.18 \%$ in the first year to $6.7 \%$ in the long term, which may mean that its effect on the change in the real exchange rate was little. While the greater reliance was on local bank financing during the study period, this may be due to the weakness of the local capital structure and its inflexibility with respect to changes in the interest rate, as is the case in most developing countries. As for the impact of the budget deficit ratio to GDP, it was 5.4\% in the first year, then decreased in the fifth year to $2.7 \%$ and returned to rise in the long term until it reached $10.8 \%$, which means that the effect of the real factors related to the budget deficit and GDP play a role Noticeable change in the real exchange rate in the long term, this result expands the results of many previous applied studies (Marinheiro, 2006), (Nazier \& Essam, 2012).

\subsection{The Second Model Results}

The second model includes five variables as well, where three variables from the first model were replaced by three new variables, budget deficit/GDP ratio was replaced by three variables that express the components of financing the budget deficit, which is ratio of domestic non-bank finance to overall budget deficit (nbf), ratio of domestic bank finance to overall budget deficit (bf), and the ratio of external financing to overall budget deficit (exf), the real interest rate has been dispensed with as an approximation of non-banking domestic finance, as well dispensing with the money supply to GDP ratio as an expression of domestic banking finance, while maintaining the growth rate of the domestic product and the real exchange rate the main of variable study, proposed an identification method based on the restrictions on the long-run properties of the IRFs. Imposes no restrictions on the short-run movements of the variables. The first three variables, gdp, nbf, bf, are stationary at the level, the fourth, dexf, is stationary at the first difference, and the last variable is stationary in the logarithm form. We estimate the model with one lag according to lag order selection criteria, AIC, SC, HQ.

\subsubsection{Impulse Response Functions}

Our focus will also be on the fifth row in Figure 7, which shows the response of the real exchange rate to the shocks of other variables in the model. the first shock showed a small decline in the real exchange rate in the long term, and the second shock showed the real exchange rates rise in the short term and its noticeable decline in the long term, and the third shock similarly led to an increase in the real exchange rate in the short term and its decline significantly in the long term, As for the fourth shock, it led to a decline in the real exchange rate in the first year, a rise in the second year, and its stability thereafter at this level. 
Response of GDP to Shock1

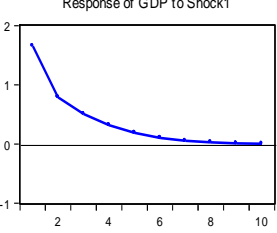

Response of NBF to Shock1

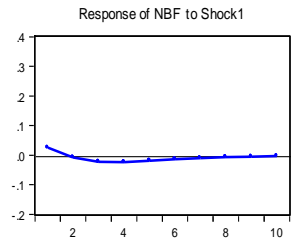

Response of BF to Shock1

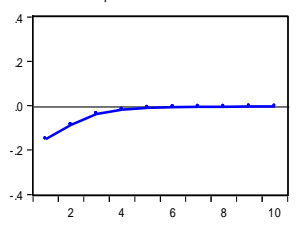

Response of DEXF to Shock1

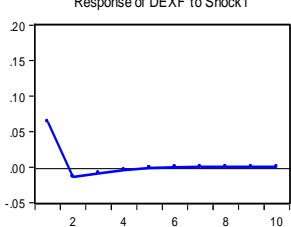

Response of LRERI to Shock

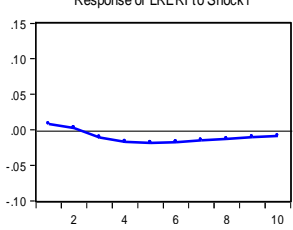

Response of GDP to Shock2

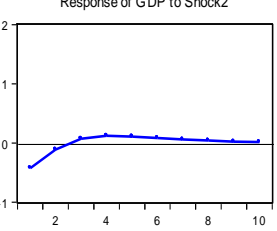

Response of NBF to Shock2

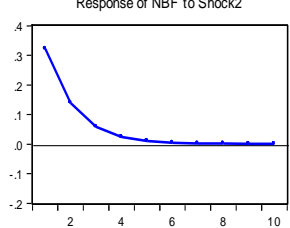

Response of BF to Shock2

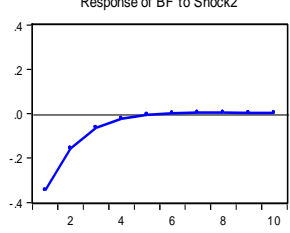

Response of DEXF to Shock2

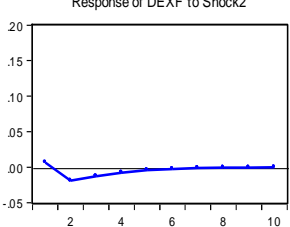

Response of LRERI to Shock2

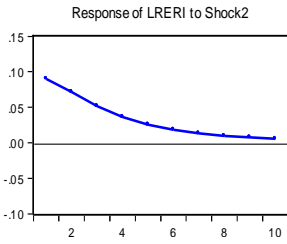

Response to Structural One S.D. Innovations

Response of GDP to Shock3

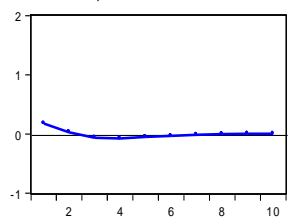

Response of NBF to Shock3

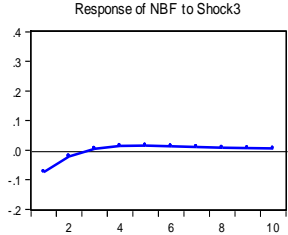

Response of BF to Shock3

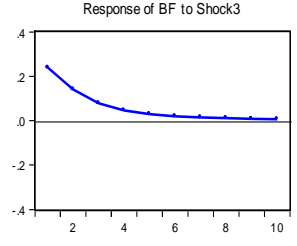

Response of DEXF to Shock3

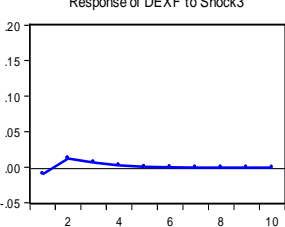

Response of LRERI to Shock3

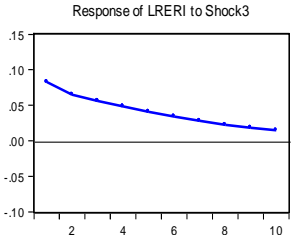

Response of GDP to Shock4

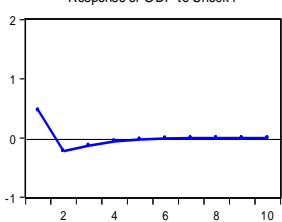

Response of NBF to Shock4

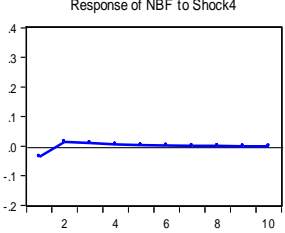

Response of BF to Shock4

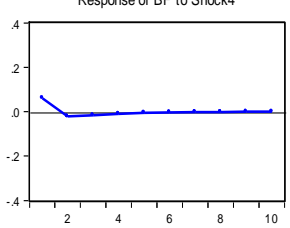

Response of DEXF to Shock4

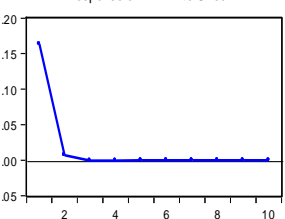

Response of LRERI to Shock4

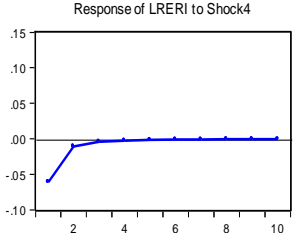

Response of GDP to Shock5

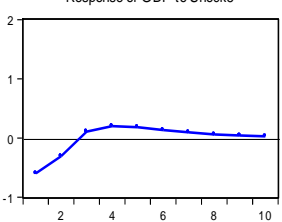

Response of NBF to Shock5
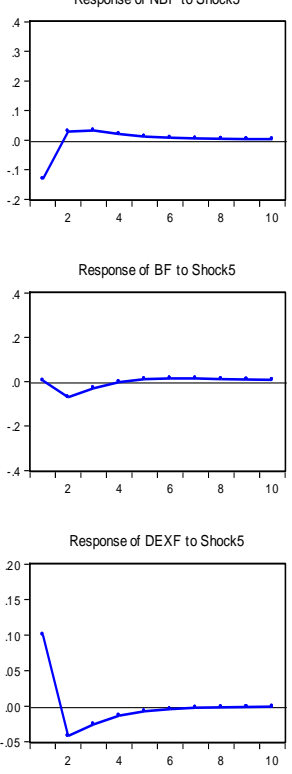

Response of LRERI to Shock5

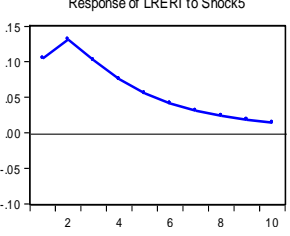

Figure 7. Impulse responses of the second model

Note. Shocks 1, 2, 3, 4, and 5 correspond to a 1 standard deviation (s.d.) shock in gdp, nbf, bf , exf, and lreri, respectively.

\subsubsection{Forecast Error Variance Decomposition}

Table 3. Forecast error variance decomposition for RERI

\begin{tabular}{cccccc}
\hline Shocks & gdp & nbf & bf & exf \\
\hline 1 year & 0.21 & 27 & 23 & 36.8 & 12.5 \\
5years & 0.93 & 20 & 20.5 & 4.4 \\
10 years & 1.75 & 19 & 22 & 4.7 & 53 \\
\hline
\end{tabular}

It is evident from Table 3, that $63 \%$ of the variation in the error in the real exchange rate is due to the effect of the four variables, and that $62 \%$ of the change in the real exchange rate in the first period is due to the three sources of financing the budget deficit, and this percentage decreased to $44.5 \%$ in the fifth year and $44 \%$ In the tenth year, which means that the sources of financing the budget deficit played an important role in the fluctuations that occurred in the real exchange rate during the study period. It is also clear that the impact of local financing, both banking and non-banking, was remarkable and ranged from $50 \%$ in the first year to $41 \%$ in the tenth year. The percentage of local bank financing also contributed significantly to the change in the real exchange rate, as it contributed $23 \%$ in the first year, $20.5 \%$ in the fifth year, and $22 \%$ in the tenth year.

\section{Discussion}

In this paper, we tried empirically to establish a dynamic relationship between the real exchange rate of the US dollar against the Egyptian pound, using variables expressing the sources of financing the budget deficit, either 
indirectly or explicitly, with the aim of testing the extent to which the budget deficit and its sources of financing contributed to the large fluctuations that occurred in the real exchange rate during the study period 1975-2020. This was done using an exactly identified SVAR approach. The results of the two models used in the paper confirm that the factors that significantly contributes in RERI fluctuations in the long term are the ratio of the budget deficit to the GDP and the rate of growth of the GDP. Therefore, reducing the proportion of the budget deficit to the GDP is one of the important policies to achieve stability in the real exchange rate and the value of the Egyptian pound relative to the dollar.

We found evidence of the contribution of the money supply ratio to the GDP in the fluctuations of the real exchange rate in the short and medium terms, while the contribution of non-bank financing expressed in the real interest rate contributed to a lesser degree in these fluctuations, which gives an indication of the expansion in the use of local bank financing to finance the budget deficit during the study period. Moreover, the results showed that the government's dependence on local sources in financing the budget deficit was large, especially the local bank financing. We also found that the non-banking domestic sources of funding have less influence on the fluctuations of the real exchange rate and therefore the value of the Egyptian pound in relation to the US dollar. furthermore, also found out that the periods in which the real exchange rate decreased and the value of the pound improved, are the periods in which the reliance on non-banking domestic financing was greater than on domestic banking financing, namely the periods from 1993-1997, and from 2005-2010.

\section{Acknowledgments}

The author appreciates Dr. Sherine El Shawarby's contribution to the first draft of this paper.

\section{References}

Abdelgany, M. (2020). Determinants of real exchange rate Evidence from Egypt. Political and economy Review, 8, 1-77. https://doi.org/10.21608/jocu.2020.37917.1041

Adebayo, A. A., \& George, E. O. (2019). Exchange rate impact of Bond-financed fiscal deficit in Nigeria. Economic Insight- Trends and Challenges, VIII(LXXI)2, 53-63.

Ahmed, S., Ickes, B., Wang, P., \& Yoo, S. (1993). International Business Cycles. American Economic Review, 83, 335-359.

Apergis, N. (1998). Budget deficit and exchange rates: Further evidence from co integration and causality testes .Journal of Economic Studies, 25, 2, 161-178. https://doi.org/10.1108/01443589810215324

Ayinde, O. T., \& Bankole, S. A. (2021). Fiscal dominance and exchange rate stability in Nigeria. Future Business Journal, (43), 1-15. https://doi.org/10.1186/s43093-021-00076-7

Barro, R. (1988). The Ricardian Approach to Budget deficits. NBER. WP No. 2685. https://doi.org/10.3386/w2685

Blanchard, O., \& Quah, D. (1989). The Dynamic Effects of Aggregate Demand and Supply Disturbances. American Economic Review, 79, 655-672. https://doi.org/10.3386/w2737

Corsetti, G., Meier, A., \& Müller, G. (2009a). Fiscal policy transmission and the exchange rate regime. Working Paper, University of Bonn.

Daly, K. J., \& Kearny, C. (1998). Fiscal financing decisions and exchange rate variability. Journal of Economic Studies, 25, 309-327. https://doi.org/10.1108/01443589810220067

Daniel, B. (2001). A fiscal Theory of Currency Crises. International Economic Review, 42(4), 969-988. https://doi.org/10.1111/1468-2354.00142

Darrat, A. F., \& Sulaman, M. O. (1991). Have budget deficit and money growth caused changes in interest rate and exchange rate in Canda. North American Review of Economics and Finance, 2(1), 69-82. https://doi.org/10.1016/1042-752X(91)90014-Q

Dissanayake, D. M. S. B. (2016). Identifying the relationships between budget deficit and selected macroeconomic variables: A study of Sri Lanka during the post-liberalization era. Paper presented at the 13th International Conference on Business Management. https://doi.org/10.2139/ssrn.2910354

Edwards, S. (1987). Exchange control devaluation and real exchange rate, The Latin American Experience. NBER, WP, 450. https://doi.org/10.3386/w2348

Edwards, S. (1989). Real Exchange rates devaluations, and Adjustment: Exchange rate policy in developing countries. MIT Press, Cambridge, Massachusetts. 
Enders, Z., Muller, G. J., \&Scholl, A. (2011). How do fiscal and technology shocks affect real exchange rate? New evidence for United States. Journal of International Economics, 83(1), 53-69. https://doi.org/10.1016/j.jinteco.2010.08.005

Hakkio, C. S. (1996). The effects of Budget deficit reduction on the exchange rate. Federal Reserve Bank of Kansas City Economic Review, Third quarter, 21-38.

Khan, R. E. A., Akhtar, A. A., \& Rana, A. S. (2002). Relationship between exchange rate and budgetary deficit: Empirical evidence from Pakistan. Journal of Applied Sciences, 2, 839-842. https://doi.org/10.3923/jas.2002.839.842

Kim, S., \& Roubini, N. (2008). Twin deficit or twin divergence? Fiscal policy, current account, and real

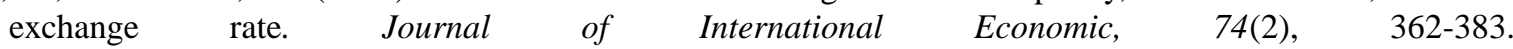
https://doi.org/10.1016/j.jinteco.2007.05.012

Marinheiro, C. (2007). Ricardian Equivalence, Twin deficits and the Feldstein - Horioka puzzle in Egypt GEMF. Facility of economics, university of Coimbra, Portugal. https://doi.org/10.2139/ssrn.1009788

Masoud, A., \& Willett. (2014). Egypt's exchange Rate Regime policy after the flout. International Journal of Social Studies, 2(4), 1-17. https://doi.org/10.11114/ijsss.v2i4.445

Mcmillin, W. D., \& Koray, F. (1990). Dose Government debt affect the exchange rate? Empirical analysis of the U.S-Canadian exchange rate. Journal of Economics and Business, 42, 279-288. https://doi.org/10.1016/0148-6195(90)90037-D

Melvin, M., Schlagenhauf, D., \& Talu, A. (1989). The U.S. Budget Deficit and the Foreign Exchange Value of the Dollar. The Review of Economics and Statistics, 71(3), 500-505. https://doi.org/10.2307/1926907

Miyamoto, W., Nguyen, T., \& Sheremirov, V. (2016). The Effects of Government Spending on Real Exchange rate Evidence from Military Spending Panel Data. Federal Reserve Bank of Boston, 16, 1-44. https://doi.org/10.2139/ssrn.2865512

Monacelli, T., \& Perotti, R. (2010). Fiscal policy, the real exchange rate, and traded goods. The Economic Journal, 120(544), 437-461. https://doi.org/10.1111/j.1468-0297.2010.02362.x

Mountford, A., \& Uhlig, H. (2009). What are the effects of policy shocks? Journal of Applied Econometrics, 24, 960-992. https://doi.org/10.1002/jae.1079

Nazier, H., \& Essam, M. (2012). Empirical investigation of twin deficits hypothesis in Egypt (1992-2010). Middle Eastern Finance and Economics, (17), 45-58.

Nour, E. D. (2017). Much Ado about the Egyptian pound exchange rate misalignment and the path towards equilibrium. ECES, 190, 1-42.

Nwaeze, N. C., Kalu, I. E., \& Tamuno, S. O. (2017). Exchange rate volatility and fiscal deficit in Nigeria Any causality? (1970-2016). Greener Journal of Economics and Accountancy, 6(3), 082-095. https://doi.org/10.15580/GJEA.2017.3.112017170

Reside, R. (2004). International Transmission of US Monetary Policy Shocks: VAR Evidence from the Philippines. UPSE Discussion Paper.

Saxena, P. S., \& Singh, V. (2020). Causal analysis of the relationship between exchange rate and government deficit: evidence from India. Business Analyst, 40(2), 175-188.

Srivyal, V., \& Venkata, S. (2004). Budget deficit and other macroeconomic variables in India. Applied Econometrics and International Development, 4(1), 37-54.

$\mathrm{Su}, \mathrm{Y} ., \& \mathrm{Su}, \mathrm{S}$. T. (2003). The impact of budget deficits on currency value: A comparison of Asian and European countries. Multinational Business Review, 11(3), 94-112. https://doi.org/10.1108/1525383X200300018

Wuyah, Y. T., \& Amwe, A. D. (2015). Impact of fiscal deficits on macroeconomic variables in Nigeria European Journal of Business and Management, 7(34), 21-26.

\section{Notes}

Note 1. RERI $I_{t}=N E R I_{t} \times \frac{\operatorname{CPIUS}_{t}}{\operatorname{CPIEG}_{t}}$ 。

Note 2. Article (47) of Central Bank Law No. 194 of 2020 "The Central Bank provides financing to the 
government upon its request to cover the seasonal deficit in the general budget, provided that the value of this financing does not exceed $(10 \%)$ of the average revenues of the general budget in the previous three years. For a period of three months, renewable for other similar periods, and it must be paid in full within twelve months at most from the date of its submission". Also, Article (46) of the same law allows the Central Bank to deal in government debt instruments in the secondary market only .

Note 3. Calculated by the author based on data obtained from Egyptian central bank time series, www.cbe.org.eg

\section{Copyrights}

Copyright for this article is retained by the author(s), with first publication rights granted to the journal.

This is an open-access article distributed under the terms and conditions of the Creative Commons Attribution license (http://creativecommons.org/licenses/by/4.0/). 